\title{
Cytolysis of Bacillus subtilis by Fusarium oxysporum
}

\author{
W. D. Grant, ${ }^{1 *}$ B. A. Prosser ${ }^{1}$ and St J. Wakefield ${ }^{2}$ \\ ${ }^{1}$ Cawthron Institute, Private Bag, Nelson, New Zealand \\ ${ }^{2}$ Department of Pathology, Wellington Clinical School of Medicine, Wellington Hospital, Wellington, New Zealand
}

(Received 8 August 1990; revised 2 October 1990; accepted 23 October 1990)

\begin{abstract}
Growth of Fusarium oxysporum on heat-killed Bacillus subtilis cells was accompanied by the loss of bacterial cytoplasmic contents, and this 'cytolysis' could be catalysed in heat-treated bacteria by the fungal culture fluids. In electron micrographs the bacterial walls appeared undamaged, and the absence of wall-lytic enzymes was confirmed by use of isolated bacterial walls as substrate. Appearance of cytolytic activity in cultures was paralleled by the production of proteolytic activity in the cultures. Proteolysis and cytolysis had similar pH optima at 8.8-9.0. Cultures grown on casein, but not glucose, produced high cytolytic activity. Rapid cytolysis occurred when heattreated $B$. subtilis cells were incubated with trypsin, subtilisin or pronase E. Viable bacteria, however, were not attacked, either by concentrated culture fluids or by the commercial protease preparations.
\end{abstract}

\section{Introduction}

A wide range of soil fungi can attack heat-killed bacterial cells, utilizing these cells as a sole source of $\mathrm{C}, \mathrm{N}$ and $\mathrm{P}$ (Fermor \& Wood, 1981; Grant et al., 1986). Although certain fungi produce extracellular bacteriolytic enzymes which attack the cell walls of the bacterial substrate, many others, including some Fusarium species, apparently degrade the cytoplasm of the bacteria without affecting the wall structure (Grant et al., 1986). This process has been termed cytolysis. We have now demonstrated quantitatively the growth of Fusarium oxysporum on Bacillus subtilis cells, and have investigated the process of cytolysis in this system. We present evidence that extracellular fungal proteases play an important part in this process. Our results suggest that cytolysis is part of a non-specific utilization of proteinaceous organic matter by the fungus, rather than a specific degradation of bacterial cytoplasm.

\section{Methods}

Organisms. The strain of Fusarium oxysporum used for this study was isolated from garden soil. Its identity has been confirmed by Dr P. G. Broadhurst, Plant Diseases Division, DSIR, Auckland, New Zealand. B. subtilis strains 168 and FJ6 were gifts from, respectively, Professor J. Mandelstam, University of Oxford, UK, and Dr R. S. Buxton, National Institute for Medical Research, London, UK.

Culture media. The standard growth medium for $F$. oxysporum was adapted from that of Scheffer \& Walker (1953) with 3\% rather than $5 \%$ (w/v) glucose, the final composition being glucose $0.167 \mathrm{M} ; \mathrm{NH}_{4} \mathrm{NO}_{3}$,
$0 \cdot 175 \mathrm{M} ; \mathrm{KH}_{2} \mathrm{PO}_{4}, 37 \mathrm{~mm} ; \mathrm{MgSO}_{4}, 10 \mathrm{~mm} ; \mathrm{FeCl}_{3}, 74 \mu \mathrm{M}$. The $\mathrm{pH}$ was 7.0. When bacteria were used as $\mathrm{C}, \mathrm{N}$ and $\mathrm{P}$ source, the glucose, $\mathrm{NH}_{4} \mathrm{NO}_{3}$ and $\mathrm{KH}_{2} \mathrm{PO}_{4}$ were replaced with freeze-dried cells of $B$. subtilis $168\left(3 \mathrm{mg} \mathrm{ml}^{-1}\right)$ prepared as described below. Glucose and $\mathrm{NH}_{4} \mathrm{NO}_{3}$ were omitted from the medium when the fungus was grown on casein (BDH, $1 \%, \mathrm{w} / \mathrm{v}$ ) as $\mathrm{C}$ and $\mathrm{N}$ source. $B$. subtilis was grown in either Nutrient Broth (Oxoid) or the defined glucose/glutamate sporulation medium, here termed S medium, of Donnellan et al. (1964) supplemented with L-tryptophan $(0.1 \mathrm{~mm})$ for strain 168 or Lmethionine ( $1 \mathrm{mM}$ ) for strain FJ6. All media were sterilized at $121{ }^{\circ} \mathrm{C}$ for $15 \mathrm{~min}$, with the exception of L-tryptophan, which was passed through a $0.2 \mu \mathrm{m}$ filter.

Preparation of B. subtilis cells as fungal growth substrate. B. subtilis 168 was grown in 1 litre batches of Nutrient Broth (Oxoid) in 5 litre Erlenmeyer flasks on a rotary shaker ( 150 r.p.m.) at $25^{\circ} \mathrm{C}$. Growth was monitored by turbidity $\left(\mathrm{OD}_{600}\right)$ readings (Pye-Unican SP6-400 spectrophotometer), and cells were harvested by centrifugation $(5000 \mathrm{~g}, 15 \mathrm{~min})$ near the end of exponential growth. The pellets were washed once with distilled water, resuspended in distilled water and heated at $100^{\circ} \mathrm{C}$ for $15 \mathrm{~min}$. The heat-killed cells were washed again in distilled water then freeze-dried from suspension in distilled water.

Growth of $F$. oxysporum on B. subtilis. A starter culture ( $25 \mathrm{ml}$ of the $B$. subtilis medium) was inoculated from a potato-dextrose agar slant of $F$. oxysporum and incubated statically at $25^{\circ} \mathrm{C}$ for $3 \mathrm{~d}$. The mycelium was then broken into small pieces by shaking with sterile glass beads in a wrist-action shaker (Griffin \& George). Aliquots $(0.5 \mathrm{ml})$ of the resulting suspension were transferred to $33 \mathrm{ml}$ of $B$. subtilis medium in $250 \mathrm{ml}$ Erlenmeyer flasks which were incubated statically at $25^{\circ} \mathrm{C}$. The flask contents were swirled daily by hand. At intervals, replicate flasks were harvested, as well as an uninoculated control flask, by centrifuging $(5000 \mathrm{~g}, 30 \mathrm{~min})$, washing the pellet once with distilled water, re-centrifuging, then freeze-drying to constant weight. The biomass of $F$. oxysporum grown on $B$. subtilis medium was estimated indirectly by extraction and measurement of the ergosterol present in the harvested material using the adaptation of the method of Seitz et al. (1979) described previously (Grant et al., 1990). Cultures of 
$F$. oxysporum grown in the standard glucose medium were used to confirm that a linear relationship existed between fungal dry weight and extractable ergosterol.

Growth and treatment of $B$. subtilis for cytolysis experiments. B. subtilis 168 was grown at $25^{\circ} \mathrm{C}$ on a rotary shaker (150 r.p.m.), harvested by centrifugation $(5000 \mathrm{~g}, 15 \mathrm{~min})$ at mid-exponential phase $\left(\mathrm{OD}_{600} 0 \cdot 4\right.$ 0.5 ), washed once with sterile $\mathrm{S}$ medium at $0{ }^{\circ} \mathrm{C}$, then treated to inactivate autolytic enzymes. Cells were suspended in $\mathrm{S}$ medium, heated at $85^{\circ} \mathrm{C}$ for $10 \mathrm{~min}$, chilled in an ice bath, centrifuged at $5000 \mathrm{~g}$, and resuspended in fresh medium. The treatment caused no detectable release of $280 \mathrm{~nm}$-absorbing material, although $>99 \%$ loss of viability occurred. Cells, whether heat-treated or not, were always used within $2 \mathrm{~h}$ of harvesting.

Cytolysis assay. Cytolysis was monitored by the decrease in $\mathrm{OD}_{600}$ caused by the loss of bacterial cytoplasmic contents. Viable or heattreated $B$. subtilis cells were suspended in sterile $\mathrm{S}$ medium at $25^{\circ} \mathrm{C}$ so that on fourfold dilution the $\mathrm{OD}_{600}$ was $0 \cdot 7-0.8$. Sterile $0.1 \mathrm{M}$ glycine $/ \mathrm{NaOH}$ buffer $\mathrm{pH} 9.0(2 \mathrm{ml})$ was added to $1 \mathrm{ml}$ of the cell suspension, followed by $1 \mathrm{ml}$ of $F$. oxysporum culture fluid, previously sterilized by passage through a $0.2 \mu \mathrm{m}$ filter. Blanks were identical buffered cell suspensions incubated with $1 \mathrm{ml}$ of sterile salts solution of the standard $F$. oxysporum medium. The initial rate of change of $\mathrm{OD}_{600}$ was taken as a measurement of cytolysis rate. Commercial enzyme preparations were also tested for cytolytic activity using this procedure. Final concentrations of these enzymes and the appropriate buffers were: trypsin (Sigma, type III), $0.5 \mathrm{mg} \mathrm{ml}^{-1}$ in $0.05 \mathrm{M}$-sodium phosphate buffer, pH 7.8; pronase E (Sigma type XIV), $0.25 \mathrm{mg} \mathrm{ml}^{-1}$ in $0.01 \mathrm{M}$-sodium phosphate buffer, $\mathrm{pH} 7.5$; subtilisin (Sigma, type VIII), $0.25 \mathrm{mg} \mathrm{ml}^{-1}$ in $0.01 \mathrm{M}$-sodium phosphate buffer $\mathrm{pH} 7.5$; lipase (Sigma, type VII), $0.2 \mathrm{mg} \mathrm{ml}^{-1}$ in $0.01 \mathrm{M}$-sodium phosphate buffer pH 7.7; phospholipase C (Sigma, type IX), $0.2 \mathrm{mg} \mathrm{m}^{-1}$ in $0.01 \mathrm{M}-$ Tris/ $\mathrm{HCl}$ buffer $\mathrm{pH} 7 \cdot 3$.

Protease assay. The procedure was an adaptation of the method of Rinderknecht et al. (1968) in which $10 \mathrm{mg}$ Hide Powder Azure (Sigma) was suspended in $2 \mathrm{ml}$ of $0.1 \mathrm{M}$-glycine/ $\mathrm{NaOH}$ buffer $\mathrm{pH} 9.0$ in a $75 \times 8 \mathrm{~mm}$ test tube, then $1 \mathrm{ml}$ of $F$. oxysporum culture fluid was added. The mixture was incubated for $60 \mathrm{~min}$ at $25^{\circ} \mathrm{C}$, agitating gently every $5 \mathrm{~min}$. The tube was cooled in an ice bath and the dye released was measured at $595 \mathrm{~nm}$. The blank was $1 \mathrm{ml} F$. oxysporum standard culture medium incubated with a buffered sample of Hide Powder Azure under identical conditions.

Electron microscopy. Cells were fixed in half-strength Karnovsky's fixative, post-fixed in osmium tetroxide, dehydrated in alcohol and embedded in Epon 812. Thin sections were stained in uranyl acetate and Reynold's lead citrate and examined in a Siemens 102 electron microscope.

Other methods. Cell walls of $B$. subtilis 168 were prepared and wall degradation assayed as described previously (Grant et al., 1990). Reducing and amino groups were measured by the procedures of Park \& Johnson (1949) and Ghuysen et al. (1966) respectively. The buffers used in establishing $\mathrm{pH}$ optima were $0.1 \mathrm{M}-\mathrm{Tris} / \mathrm{HCl}(\mathrm{pH} \mathrm{7 \cdot 3-9.0)}$ and $0.1 \mathrm{M}$-glycine $/ \mathrm{NaOH}(\mathrm{pH} \mathrm{9.0-11.0)}$. Where required, culture fluids were concentrated by ultrafiltration on an Amicon YM-10 filter.

\section{Results}

$F$. oxysporum will grow at the expense of viable $B$. subtilis cells, but the process is difficult to investigate because the bacteria autolyse before appreciable fungal growth occurs. Growth of the fungus on heat-killed $\left(100^{\circ} \mathrm{C}\right)$

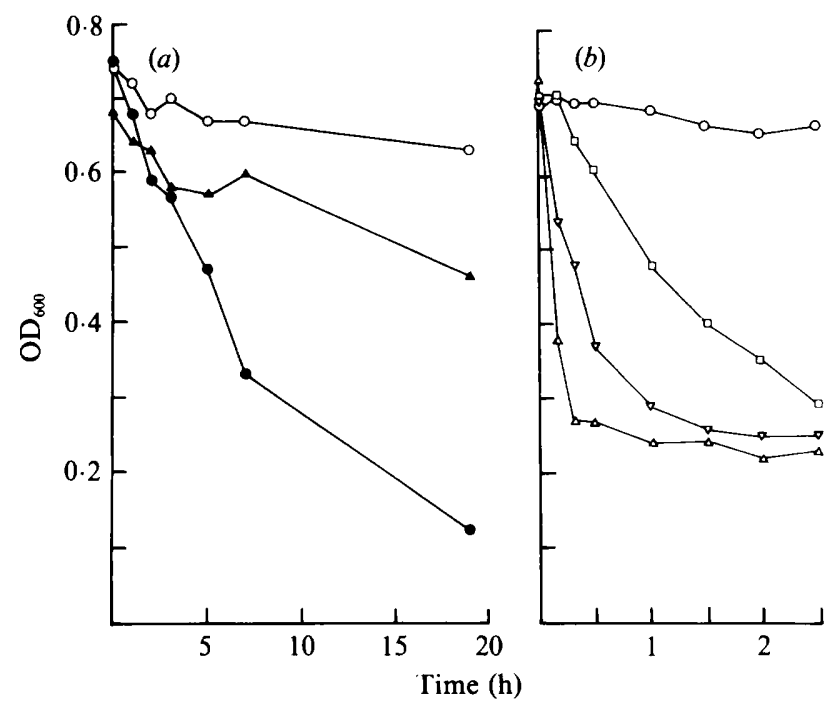

Fig. 1. Cytolysis of heat-treated $\left(85^{\circ} \mathrm{C}, 10 \mathrm{~min}\right) B$. subtilis cells, $(a)$ on incubation with culture fluids from $F$. oxysporum grown on $B$. subtilis $(\boldsymbol{O})$ or on standard glucose medium $(\boldsymbol{A})$; and $(b)$ on incubation with pronase $\mathrm{E}(\triangle)$, subtilisin $(\square)$ and trypsin $(\nabla)$ at, respectively, $0 \cdot 25,0 \cdot 25$ and $0.5 \mathrm{mg} \mathrm{ml}^{-1}$, final concentrations. $\bigcirc$, Control cells incubated in absence of culture fluids or enzymes.

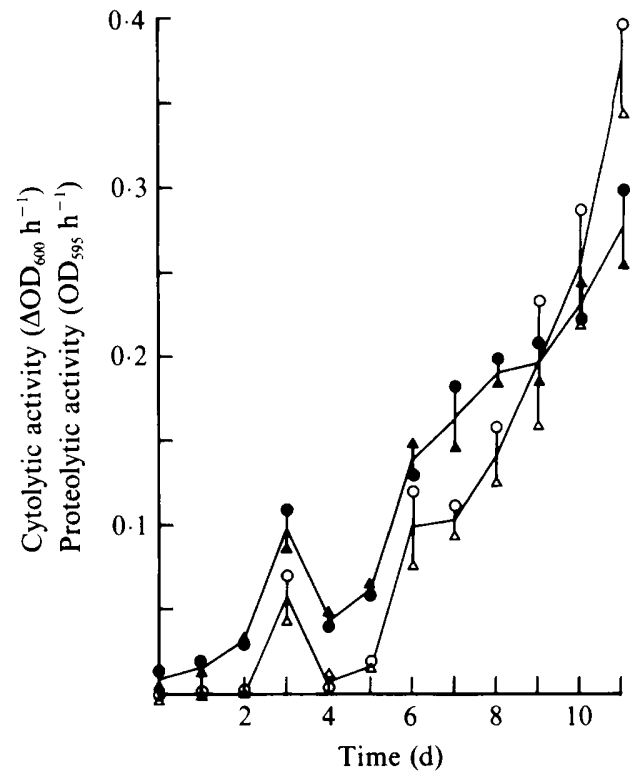

Fig. 2. Production of cytolytic activity (solid symbols) and proteolytic activity (open symbols) by duplicate cultures of $F$. oxysporum growing on $B$. subtilis medium at $25^{\circ} \mathrm{C}$.,$\bigcirc$, Culture $\mathrm{A} ; \boldsymbol{\Delta}, \triangle$, culture $\mathrm{B}$. Cytolytic and proteolytic activities were measured as described in Methods.

B. subtilis cells as sole $\mathrm{C}, \mathrm{N}$ and $\mathrm{P}$ source occurred over $9 \mathrm{~d}$ incubation at $25^{\circ} \mathrm{C}$, as shown by the increase in ergosterol content of the biomass from $<0.05$ (detection limit) to $3.59 \pm 0.42 \mu \mathrm{g}$ (ml culture) ${ }^{-1}$ (mean of four flasks, $\pm \mathrm{SD})$, and decrease in the total dry weight of cell material (fungus plus bacteria) from $2 \cdot 90 \pm 0 \cdot 14$ to 

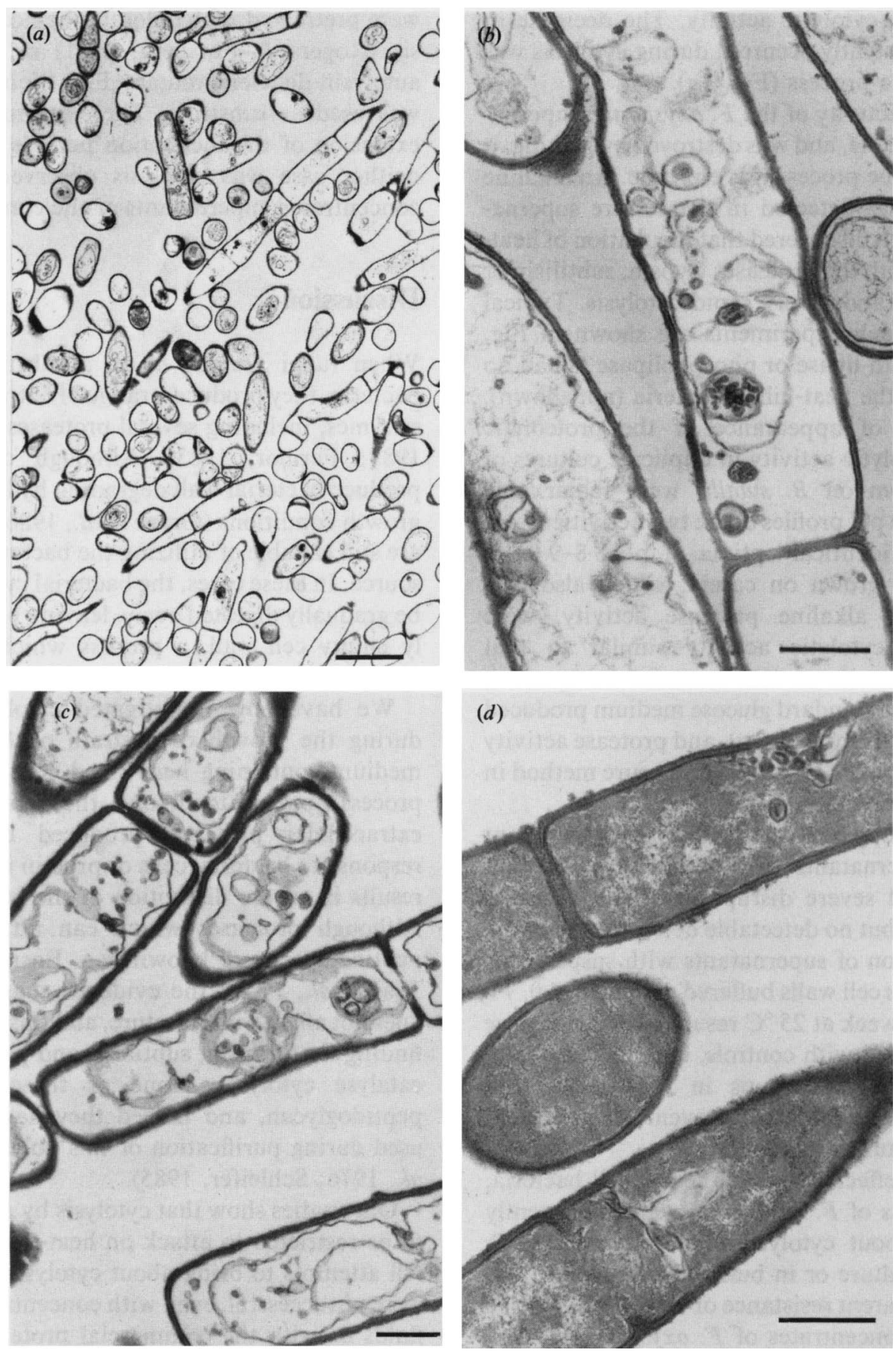

Fig. 3. Cells of B. subtilis were pretreated at $85^{\circ} \mathrm{C}$ for $10 \mathrm{~min}$, then incubated $(a, b)$ for $24 \mathrm{~h}$ with culture fluid of $F$. oxysporum buffered at pH $9.0 ;(c)$ for $22 \mathrm{~h}$ with pronase $\mathrm{E}\left(0.25 \mathrm{mg} \mathrm{ml}^{-1}\right)$ buffered at $\mathrm{pH} 7.5$; and $(d)$ for $24 \mathrm{~h}$ with pH 9.0 buffer alone. Bars, $2 \mu \mathrm{m}(a), 0.5 \mu \mathrm{m}$ $(b, c, d)$.

$1.65 \pm 0.05 \mathrm{mg}$ ( $\mathrm{ml}$ culture $)^{-1}$ (mean of five flasks each, $\pm \mathrm{SD})$. As the fungus grew, the bacteria appeared to lose their cytoplasmic contents until, when viewed under phase-contrast microscopy, they resembled empty cell walls. This phenomenon, which we have termed cytolysis (Grant et al., 1986), also occurred when cell-free supernatants of $F$. oxysporum cultures were incubated with heat-killed $\left(100^{\circ} \mathrm{C}\right) \mathrm{B}$. subtilis cells, or with freshlygrown bacteria which had been more mildly heat-treated $\left(85^{\circ} \mathrm{C}\right.$ for $\left.10 \mathrm{~min}\right)$ to inactivate autolytic enzymes without causing major structural damage. Supernatants of the fungus grown on the standard glucose medium 
showed little or no cytolytic activity. The decrease in $\mathrm{OD}_{600}$ which consistently occurred during cytolysis was used to quantify the process (Fig. 1a).

As the cytolytic activity of the $F$. oxysporum supernatants was not dialysable, and was destroyed by heating, it seemed likely that the process was enzymic. An alkaline protease activity was detected in the culture supernatants, and it was then discovered that incubation of heattreated $B$. subtilis with the proteases trypsin, subtilisin or pronase $\mathrm{E}$ brought about very rapid cytolysis. Typical results of several such experiments are shown in Fig. $1(b)$. Incubation with lipase or phospholipase $\mathrm{C}$ had no apparent effect on the heat-killed bacteria (not shown). The time courses of appearance of the proteolytic enzyme and of cytolytic activity in duplicate cultures of $F$. oxysporum grown on $B$. subtilis were remarkably similar (Fig. 2). The $\mathrm{pH}$ profiles of the two activities were also similar, with identical optima at $\mathrm{pH} \mathrm{8 \cdot 8-9 \cdot 0.F}$. oxysporum cultures grown on casein, which also produced extracellular alkaline protease activity, were found to possess cytolytic activity similar to that obtained during growth on the bacteria. In contrast, cultures grown in the standard glucose medium produced only low levels of activity (Fig. $1 a$ ), and protease activity was not detectable by the Hide Powder Azure method in supernatants of these cultures.

Electron microscopy of $B$. subtilis cells after treatment with cytolytic supernatants of $F$. oxysporum, or with pronase E, showed severe disruption of the bacterial cytoplasm (Fig. 3), but no detectable deterioration of the cell walls. Incubation of supernatants with suspensions of isolated $B$. subtilis cell walls buffered at $\mathrm{pH} 2 \cdot 8,4 \cdot 0,7 \cdot 0$ and 9.0 for up to a week at $25^{\circ} \mathrm{C}$ resulted in no decrease in turbidity compared with controls, and no changes in free amino or reducing groups in the walls. Wall degradation was not observed, even with 20 -fold concentrates of culture supernatants.

In spite of their effectiveness on heat-killed bacteria, culture supernatants of $F$. oxysporum were consistently unable to bring about cytolysis of viable cells of $B$. subtilis, either in culture or in buffered suspensions. To investigate this apparent resistance of viable $B$. subtilis to cytolysis, tenfold concentrates of $F$. oxysporum culture supernatant were incubated with freshly grown exponential-phase $B$. subtilis cells. In contrast to the relatively rapid attack of such concentrates on heat-killed bacteria, no cytolysis of the viable cells occurred, although the autolytic degradation of the cells over the long incubation period made interpretation difficult. To avoid this problem, pronase $\mathrm{E}$, which brings about rapid cytolysis (Fig. $1 b$ ) was used, but again there was no detectable cytolysis of the viable cells. Trypsin and subtilisin, similarly, had no effect on live bacteria. In other experiments to test cytolysis of viable cells, the bacteria were pretreated with chloramphenicol to inhibit autolysis (Rogers \& Forsberg, 1971) or, alternatively, the autolysin-deficient mutant FJ6 (Fein \& Rogers, 1976) was used as substrate. These approaches allowed the extension of the incubation periods to $26-36 \mathrm{~h}$, but in neither case was cytolysis observed, with either the concentrated supernatants or the commercial proteases.

\section{Discussion}

When fungi are grown on a substrate of heat-killed bacteria, they produce a range of extracellular hydrolytic enzymes, including several proteases (Fermor \& Wood, 1981; Fermor, 1983). Although certain fungi also produce bacterial wall degrading hydrolases under these growth conditions (Grant et al., 1986), many do not, yet are still capable of utilizing the bacteria as their nutrient source. In these cases, the bacterial cytoplasm appears to be gradually digested away, leaving behind an apparently empty cell wall, a process which we have termed cytolysis (Grant et al., 1986).

We have now investigated cytolysis quantitatively during the growth of a strain of $F$. oxysporum on a medium containing heat-killed cells of $B$. subtilis. The process appears to involve the action of at least one extracellular protease, produced by the fungus in response to bacterial cells or protein in the medium, and results in severe disruption of the bacterial cytoplasm. Although proteases which can attack bacterial wall peptidoglycan are known (e.g. Ensign \& Wolfe, 1965; Tsai et al., 1965), the evidence suggests that cytolysis does not affect wall structure, and this is supported by the finding that trypsin, subtilisin and pronase $E$ could also catalyse cytolysis. None of these proteases attack peptidoglycan, and indeed they have frequently been used during purification of this polymer (e.g. Brown $e t$ al., 1976; Schleifer, 1985).

Our studies show that cytolysis by $F$. oxysporum seems to be restricted to attack on heat-treated bacteria only. All attempts to bring about cytolysis of viable bacteria were unsuccessful, even with concentrated fungal culture fluids or with the commercial proteases. These results suggest that some degree of damage, probably of the cytoplasmic membrane, was a prerequisite for cytolysis to occur: even the relatively mild conditions used to inactivate the $B$. subtilis autolytic enzymes would have caused some membrane damage (Miller \& Ordal, 1972), thus making the cell contents vulnerable to attack by external hydrolases, proteases in particular.

Although bacterial cytolysis by fungi has not been described previously, proteolytic 'emptying' of bacteria has been reported several times in the literature. Norris (1957) found a 'lytic principle' in the supernatant fluid of 
Bacillus cereus M8 which lysed thiomersal-treated or heat-killed cells of seven Bacillus species, leaving intact cell walls 'almost devoid of contents'. Shirai \& Aida (1980) showed that trypsin rapidly degraded heated cells of Bacillus colistinus, although in this case significant lysis occurred with viable cells. Their electron micrograph of trypsin-treated $B$. colistinus was remarkably similar to ours of $B$. subtilis in Fig. 3. Finally, Bush (1985) showed that purified proteases 'lysed' cells of several methanogenic bacteria, leaving the cell walls largely intact. Cultures or freshly harvested cells were again insensitive to this lysis. Bush (1985) was also unable to identify the site of damage responsible for lysis. A corollary from these reports and the present work is that true lysis of bacteria, in the sense of destruction of the cell structure caused by enzymic hydrolysis of the wall, cannot simply be assumed when an extract or culture filtrate brings about a turbidity loss in a bacterial suspension. Proteolytic 'emptying' of the cell has the same effect (Fig. 3). Assumptions of wall hydrolysis have been made in the past (e.g. Lynn, 1989). Such assumptions need to be verified by electron microscopy and by use of isolated cell walls as enzyme substrates.

Although it is possible that $F$. oxysporum and other fungi could produce proteases specifically for the degradation of bacteria in their immediate environment, it seems likely that such enzymes would be capable of attacking live bacteria. As this has not been observed, a more plausible explanation of cytolysis is that it represents a non-specific proteolysis induced by the presence of proteinaceous material. As shown in Fig. 1, cytolytic activity was low in the supernatant of glucosegrown $F$. oxysporum, and the cytolytic properties of supernatants after growth on casein support this interpretation. The capacity of several different proteases to catalyse cytolysis is further evidence for a non-specific process. Finally, one would expect an ability to attack proteinaceous material to be widespread in soil fungi: in a recent survey of soil fungi, we detected cytolysis in 73 out of 89 isolates (B. A. Prosser \& W. D. Grant, unpublished observations). Since cytolysis occurs only with damaged bacteria, the fungi which carry out this process are acting as opportunistic 'saprophytes', in contrast to those species which can produce enzymes to degrade bacterial walls. These latter fungi can be regarded, in a sense, as 'predatory', since they are capable of attacking and utilizing viable bacteria as their nutrient source.
We thank Mr Alfred Harris, formerly of Wallaceville Agricultural Research Centre, Upper Hutt, New Zealand, for his help with preliminary electron microscopy work. This project was carried out as part of a research contract with the New Zealand Government, and supported by the New Zealand Lottery Grant Board.

\section{References}

Brown, W. C., Doyle, R. J. \& Streips, U. N. (1976). Comparison of various procedures for removing proteins and nucleic acids from cell walls of Bacillus subtilis. Preparative Biochemistry 6, 479-488.

Bush, J. W. (1985). Enzymatic lysis of the pseudomurein-containing methanogen Methanobacterium formicicum. Journal of Bacteriology 163, 27-36.

Donnellan, J. E., JR, Nags, E. H. \& Levinson, H. S. (1964) Chemically-defined, synthetic media for sporulation and for germination and growth of Bacillus subtilis. Journal of Bacteriology 87, 332 336.

ENSIGN, J. C. \& WolFE, R. S. (1965). Lysis of bacterial cell walls by an enzyme isolated from a Myxobacter. Journal of Bacteriology $90,395-$ 402.

Fein, J. E. \& Rogers, H. J. (1976). Autolytic enzyme-deficient mutants of Bacillus subtilis 168. Journal of Bacteriology 127, 1427-1442.

FERMOR, T. R. (1983). Fungal enzymes produced during degradation of bacteria. Transactions of the British Mycological Society 80, 357-360.

FERMOR, T. R. \& WOOD, D. A (1981). Degradation of bacteria by Agaricus bisporus and other fungi. Journal of General Microbiology 126, 377-387.

Ghuysen, J.-M., Tipper, D. J. \& Strominger, J. L. (1966). Enzymes that degrade bacterial cell walls. Methods in Enzymology 8, 685-699.

Grant, W. D., Rhodes, L. L., Prosser, B. A. \& Asher, R. A. (1986). Production of bacteriolytic enzymes and degradation of bacteria by filamentous fungi. Journal of General Microbiology 132, 2353-2358.

Grant, W. D., Prosser, B. A. \& ASHER, R. A. (1990). A bacteriolytic muramidase from the basidiomycete Schizophyllum commune. Journal of General Microbiology 136, 2267-2273.

LYNN, K. R. (1989). A lysozyme from the fruit Actinidia chinensis. Phytochemistry 28, 2267-2268.

MiLleR, L. L. \& ORDAL, Z. J. (1972). Thermal injury and recovery of $B$. subtilis. Applied Microbiology 24, 878-884.

NoRRIS, J. R. (1957). A bacteriolytic principle associated with cultures of Bacillus cereus. Journal of General Microbiology 16, 1-8.

PARK, J. T. \& JOHNSON, M. J. (1949). A submicrodetermination of glucose. Journal of Biological Chemistry 181, 149-151.

Rinderknecht, H., Geokas, M. C., SilvermanN, P. \& Haverback, B. J. (1968). A new ultrasensitive method for the determination of proteolytic activity. Clinica Chimica Acta 21, 197-203.

Rogers, H. J. \& ForsberG, C. W. (1971). Role of autolysins in the killing of bacteria by some bactericidal antibiotics. Journal of Bacteriology 108, 1235-1243.

SCHEFFER, R. P. \& WALKeR, J. C. (1953). The physiology of Fusarium wilt of tomato. Phytopathology 43, 116-125.

SCHLEIFER, K. H. (1985). Analysis of the chemical composition and primary structure of murein. Methods in Microbiology 18, 123-156.

Seitz, L. M., Sauer, D. B., Burroughs, R., Mohr, H. E. \& Hubbard, J. D. (1979). Ergosterol as a measure of fungal growth. Phytopatho$\log y$ 69, 1201-1203.

SHIRAI, M. \& AIDA, T. (1980). Autolysis of Bacillus colistinus. Agricultural and Biological Chemistry 44, 1513-1519.

TSai, C. S., Whitaker, D. R., JuRasek, L. \& Gillespie, D. C. (1965). Lytic enzymes of Sorangium sp. Action of the $\alpha$ - and $\beta$-lytic proteases on two bacterial mucopeptides. Canadian Journal of Biochemistry 43, 1971-1983. 